\title{
Mangrove Vegetation Structure and Its Carbon Stock Potency in Bunaken National Park, North Sulawesi
}

\author{
Joi Daniel Kimbal ${ }^{1}$, Soemarno ${ }^{2}$, Bagyo Yanuwiadi ${ }^{3}$, Sudarto $^{2}$ \\ ${ }^{I}$ Graduate Program of Agriculture, Faculty of Agriculture, Brawijaya University Malang, and Lecturer of \\ Department of Biology, Faculty of Mathematics and Natural Sciences, Manado State University, Tondano, \\ North Sulawesi \\ ${ }^{2}$ Faculty of Agriculture, Brawijaya University Malang \\ ${ }^{3}$ Department of Biology, Faculty of Mathematics and Natural Sciences, Brawijaya University
}

\begin{abstract}
Aims of this research are to describe structure of mangrove vegetation and its potential of carbon stock in northern area of the Bunaken National Park. Totally, there are about 18 mangrove species growing in coastal area of Bunaken. In Teling areas, $R$. mucronata and $S$. alba become two co-dominant species in plot 1 , $S$. alba become important species in plot 2, and R. apiculata is the important species in plot 3 . Avicennia marina become the most important species in Rap-rap. In Pungkol, B. sexangula has highest value of important value index in Plot 1 , followed by $R$. mucronata in Plot 2 and B. parviflora in plot 3. In Wawontulap areas, B. parviflora has the highest value of important value index. The highest carbon stock was found at Rap-rap (ca. $1784,68 \mathrm{Mg} / \mathrm{ha}$ ) and the lowest was found at Wawontulap (390,03 $\left.\mathrm{Mg} \mathrm{ha}^{-1}\right)$. The highest necromass was found at Teling ( $\mathrm{ca} 208,79 \mathrm{Mg} \mathrm{ha}^{-1}$ ) and the lowest was found at Wawontulap (ca. 21,30 Mg ha $\mathrm{C}^{-1}$. Mangrove ecosystem in the Bunaken National Park is important for global warming mitigation through their ecosystem ability to absorb $\mathrm{CO}_{2}$ and store carbon into vegetation biomass and necromass.
\end{abstract}

Keywords: Bunaken National Park, mangrove, Global warming, biodiversity conservation, Carbon stock

\section{Introduction}

Recent global industrialization and development program lead to the increase of greenhouse gases. Decrease of forest cover due to rapid deforestation, land uses changes and forest fire triggering increase of green houses in the globe. Scholar point out those problems contributes to the $18 \%-20 \%$ of total greenhouses gases emissions. Carbon dioxide is the most abundance greenhouse gases which are related to industrialization [1] [2] [3] [4].

In 2009, United Nations report the ecosystems degradation in coastal and marine environments potentially reduces the ability of such ecosystem in greenhouse gases emission reduction. Coastal forest, mangrove, peat and sea grass able to absorb 1.65 billion ton of $\mathrm{CO}_{2}$. Unfortunately, many of them are disturbed and degraded in significant rates. United nation report that coastal habitat decrease $7 \%$ yearly. In 1940, about 90\% of mangrove in Asian degraded [3] [5]. Deforestation and forest degradation contributes 17,4\% global greenhouses [6]. Coastal degradation has been considered important for human being, especially for human in coastal area [7]. About 50\% of world population located at the coastal area or area within 65 miles from coastal line. In such area there are business and industrial area, tourism centre, human settlement, and educational area. The protection of coastal environment is therefore crucial [8].

Vegetation in the earth contributes to the carbon capture and sequestration. The photosynthesis process in plant is the important key in carbon capture. The photosynthesis absorbs $\mathrm{CO}_{2}$ and biochemically convert to the carbohydrates molecules. Carbohydrates is the basis component of plant biomass. The plant's biomass therefore rich in carbon content. The fundamental plants metabolism lead to the opportunities to uses plants to reduce $\mathrm{CO}_{2}$ in atmosphere. Forest conservation, therefore becomes important. In man-influenced ecosystem, there is possibility to increase ecosystem ability to absorb $\mathrm{CO}_{2}$ through sustainable agroforestry practices, comprehensive urban park design and tourism park management [9] [10] [11].

Indonesian national park is the important site for global biodiversity conservation. This protected area is one of the potential sites for the global carbon capture and sequestration strategy implementation. National park contains numerous plants species which are important for global carbon capture and sequestration. Recent condition of Indonesia national park, however, under serious threats [12] [13]. Bunaken National Park in North Sulawesi is home of biodiversity. There are about 351 ha mangrove ecosystem in Bunaken National Park. The existence of mangrove in Bunaken National Park, however, is under serious threat due to human activity. During 1982-1993 mangrove area reported decrease with average rate 17.70\% [14] [15]. In Bunaken, especially mangrove in the north part of the island, the potential of mangrove vegetation to absorb $\mathrm{CO}_{2}$ is rarely discussed. The aims of the research are to describe the recent vegetation structure of mangrove and its potential carbon stock in northern area of Bunaken National Park. Focus will be paid to the mangrove trees species. 


\section{Study site}

\section{Methods}

Research was set up at Bunaken Island in North Sulawesi. The island and its adjacent water environment were rich in term of biodiversity. Bunaken is one of the famous nature-based tourism or ecotourism destinations in Indonesia. The terrestrial and marine biodiversity has been reported high. The coral reef with numerous coral fish found in northern area of the park. The park (ca. 89.065 hectare) is important habitat for Macaca nigra nigra, Cervus timorensis russa and Ailurops ursinus ursinus. The northern area dominated by mangrove ecosystem while the south was rich in coral reefs. There are numerous diving sites in such area. In the southern part is the habitat for mangrove biota. The mangrove ecosystem has been identified crucial in Bunaken islands [14] [16] [17].

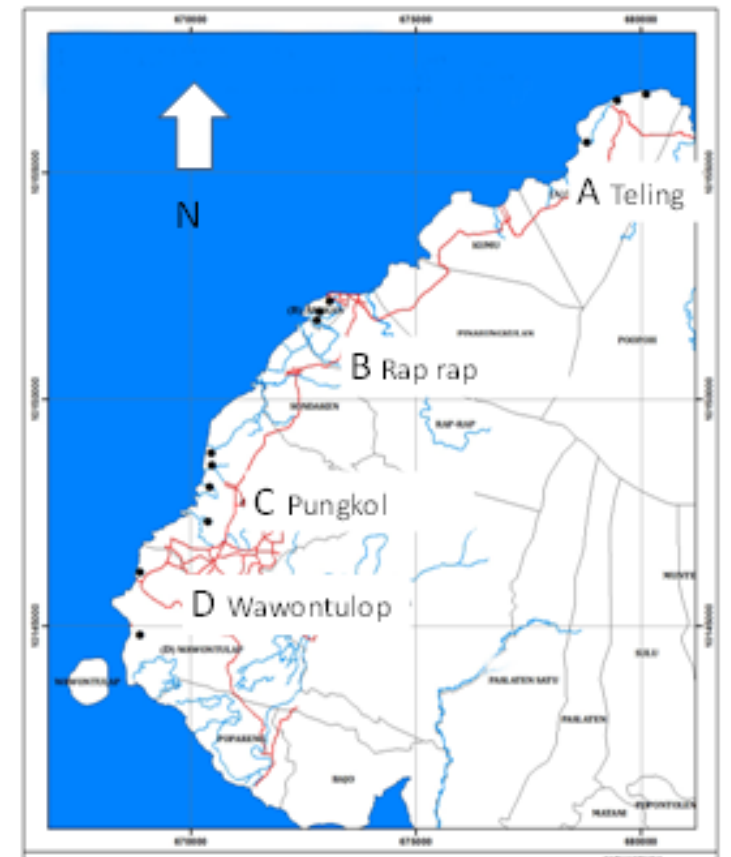

Fig. 1. Study site (A) Teling, (B) Rap-rap, (3) Pungkol and (4) Wawontulap

\section{Methods}

\section{Vegetation structure}

The survey of vegetation structure in mangrove ecosystem was carried in four villages, namely Teling, Rap-rap, Pungkol dan Wawontulap. In each villages, three observation plot by $10 \times 10 \mathrm{~m}$ was established. The first plot was set up at the adjacent to the local settlement, river and villages roads. The second plot was established at the middle distance of first and thirds plots. The thirds plot was established far from the local settlement, river and villages roads. Totally there are 12 observation plot (Fig.1). Vegetation analysis was focused to the tree species. Mangrove shrubs and herbs were excluded. In each plot, mangrove tree species was identified and calculated systematically. Data were stored in field data sheets for further analysis. The plants species biomass was measured and necromass assessed using standard methods [18] [19].

\section{Plants biomass assessment}

All of the trees species was identified and the diameter at breast height of each plants were measured through the non destructive techniques. Plant biomass was estimated by measuring diameter at breast height at $1.3 \mathrm{~m}$ height. The biomass is expressed in dry weight. It was calculated using allometric equations:

$\mathrm{DW}=0,11 \rho \mathrm{D}^{2,62}$

With:

DW $=$ dry weight

$\mathrm{D}=$ steam diameter $(\mathrm{cm})$

$\mathrm{H}=$ plant height $(\mathrm{cm})$

$\rho=$ Specific weight of wood $\left(\mathrm{g} \mathrm{cm}^{-3}\right)$. 


\section{Woody necromass}

Necromass consist of woody dead plant, dead branch and plant debris. Necromass analysis was conducted by collected woody dead plant and dead branch with diameter $5 \mathrm{~cm}$ and $50 \mathrm{~cm}$ in length. Necromass sample was collected through non destructive sampling. Necromass biomass calculation was done by measuring woody dead plant and dead branch with diameter $5 \mathrm{~cm}$ and $50 \mathrm{~cm}$ in length. Sample was collected and transferred to laboratory for dried at $80^{\circ} \mathrm{C}$ during 48 hours, and the specific weight was measured. The woody mangrove necromass was calculated followed formula:

Biomass $=\pi \mathrm{r}^{2}\left(\mathrm{~cm}^{2}\right) \times$ length $(\mathrm{cm}) \times$ Wood specific weight $\left(\mathrm{g} \mathrm{cm}^{-3}\right)$

Carbon content analysis

Carbon content analysis was calculated using formula:

Basal area $\left(\mathrm{m}^{2}\right)=1 / 4 \pi \times \mathrm{D}^{2} \times 10^{-4}$

With:

$\mathrm{D}=$ Plant diameter, measured at $1,3 \mathrm{~m}$ from land surface

\section{Mangrove vegetation structure}

\section{Result and Discussion}

In Teling Rhizophora mucronata and Soneratia alba become two co-dominant species in plot 1, shows that these two species play important role in mangrove ecosystem. In Plot 2, Soneratia alba become important species while in plot 3 Rhizophora apiculata is the important species. Sonneratia alba found in three plots with high value of important value index (Table 1). This data shows that $S$. alba contributes to the characteristic of mangrove ecosystem in Teling. Sonneratia alba has been identified tolerate wide fluctuations in water salinity. The species often grow on exposed mud-flats in coastal environment [20].

Avicennia marina become the most important species to characterized mangrove ecosystem in Rap-rap. Among the woody mangrove plant species, Avicennia marina has highest value of important value index (Table 2). Avicennia marina commonly found in South East Asia, but recent status of the population in many mangrove ecosystem has been reported decreased [21]. Human exploitation to Avicennia marina population has been caused population decrease in the wild. The existence of Avicennia marina population in Bunaken National Park, therefore should be protected in integrative strategy.

In Pungkol, Bruguiera sexangula has highest value of important value index in Plot 1 , followed by $R$. mucronata in Plot 2 and B. parviflora in plot 3. R. mucronata however, consistent to found in Pungkol. This species considered as one of the most wide spread species in Southeast Asia.

In Wawontulap, B. parviflora has the highest value of important value index in Plot 1, 2 and 3, indicated that the species plays important role to construct mangrove characters in Wawontulap. B. parviflora widely distributes in South Asia and Malesia phytoregion, including Indonesia archipelago.

The existence of mangrove ecosystem in Bunaken national park is one of the key for sustainable development in Bunaken Island. Mangrove is important habitat to support marine-based industry. It is because mangrove is habitat for numerous marine living creature which are important for local economic development [22]. Therefore, there is integrative development strategy needed. It will be necessary to obtain comprehensive support. It is encompasses evolving local community and stakeholder into conservation effort [23] [24] [25]. Native forest ecosystem structure and composition is a main factor to be taken into account when degraded native ecosystem is repaired [13]. In mangrove conservation effort in Bunaken National Park, however, this research data can be crucial as a complementary data. No restoration program is likely to be successful unless it arises from complete basis data.

Table 1. Important value index of woody mangrove species in Teling, Rap-rap, Pungkol and Wawontulap

\begin{tabular}{|c|c|c|c|c|c|c|c|c|c|c|c|c|}
\hline \multirow[t]{2}{*}{ Species } & \multicolumn{3}{|l|}{ Teling } & \multicolumn{3}{|c|}{ Rap-rap } & \multicolumn{3}{|c|}{ Pungkol } & \multicolumn{3}{|c|}{ Wawontulap } \\
\hline & plot 1 & plot 2 & plot 3 & plot 1 & plot 2 & plot 3 & plot 1 & plot 2 & plot 3 & plot 1 & plot 2 & plot 3 \\
\hline A. marina & & & 67.72 & 178.9 & 86.13 & 70.18 & 48.71 & & & & & \\
\hline A. lanata & & & & 60.21 & & & 45.90 & & & & & \\
\hline A. officinalis & 52.57 & 95.19 & & & & 27.50 & 50.99 & & & & & \\
\hline B.cylindrica & & & & & 20.76 & & & & & & & \\
\hline Ae. floridum & & & & 60.90 & & & & & & & & \\
\hline B. gymnorrhiza & & & & & 21.13 & & & & & & & \\
\hline B. parviflora & & & & & 31.88 & & & 96.95 & 124.91 & 96.25 & 95.21 & 106.50 \\
\hline B. sexangula & & & & & & & 129.44 & & & & & \\
\hline C. tagal & & & & & 20.63 & 54.44 & & & & & 40.99 & \\
\hline C. decandra & & & & & & & & 47.45 & & & & \\
\hline N. fruticans & & & & & 81.28 & & & & & & & \\
\hline
\end{tabular}


Mangrove Vegetation Structure and Its Carbon Stock Potency in Bunaken National Park, ....

\begin{tabular}{|c|c|c|c|c|c|c|c|c|c|c|c|}
\hline R. mисronata & 127.2 & - & - & & & 75.99 & 118.38 & 112.29 & & & \\
\hline R. stylosa & & & & & & & 37.22 & 62.80 & 56.60 & & 42.36 \\
\hline R. apiculata & 0.42 & 69.00 & 145.85 & & & 84.44 & & & 84.15 & 82.06 & 60.55 \\
\hline S. alba & 120.3 & 135.8 & 86.43 & & & & & & & & \\
\hline$X$. mekongensis & & & & & 47.88 & & & & 63.00 & 81.75 & 41.59 \\
\hline X. moluccensis & & & & 38.19 & & & & & & & 49.00 \\
\hline
\end{tabular}

\section{Carbon stock in mangrove vegetation}

The major mangrove species found in Teling were encompasses Rhizophora mucronata, Avicennia officinalis, Soneratia alba, Rhizophora apiculata and Avicennia marina. In Rap-rap observation station, mangrove species encompasses Aegiceras floridum, Avicennia marina, Avicennia lanata, Rhizophora apiculata, Xylocarpus mekongensis, Avicennia officinalis, Ceriops tagal, Nipah fruticans, Xylocarpus moluccensis, Bruguiera gymnorrhiza, Bruguiera cylindrica, and Bruguiera parviflora. In Pungkol, mangrove species encompasses Rhizophora mucronata, Bruguiera parviflora, Rhizophora stylosa, Ceriops decandra, Avicennia officinalis, Bruguiera sexangula, Rhizophora apiculata, Avicennia lanata and Avicennia marina. In Wawontulap station, mangrove encompasses Xylocarpus mekongensis, Bruguiera parviflora, Rhizophora apiculata, Ceriops tagal, Xylocarpus moluccensis, Rhizophora stylosa, Rhizopora mucronata and Bruguiera sexangula.

Totally, there are about 18 mangrove plants species grows in coastal area of Bunaken. This data shows that mangrove species diversity as abundance, and mangrove composed from multi species. These will become the ideal habitat for birds and aquatic species which area depend on mangrove ecosystem. The conservation of mangrove in Bunaken coastal area therefore contributes to the integral strategy of biodiversity conservation in Bunakan national Park. The existence of mangrove contributes to the protection of coastal ecosystem which is important for human [26]. It is particularly important due to Bunaken is one of the spot of tourism activities in North Sulawesi [16] [17]. The biomass of mangroves plant tree species was presented at Table 2.

Table 2. Mangrove plants biomass in observation plots $\left(\mathrm{Mg} \mathrm{ha}^{-1}\right)$

\begin{tabular}{|c|c|c|c|c|c|c|c|c|c|c|c|c|}
\hline \multirow[t]{2}{*}{ Species } & \multicolumn{3}{|l|}{ Teling } & \multicolumn{3}{|l|}{ Rap-rap } & \multicolumn{3}{|c|}{ Pungkol } & \multicolumn{3}{|c|}{ Wawontulap } \\
\hline & plot 1 & plot 2 & plot 3 & plot 1 & plot 2 & plot 3 & plot 1 & plot 2 & plot 3 & plot 1 & plot 2 & plot 3 \\
\hline A. marina & & & 49.99 & 799.36 & 32.26 & 265.46 & & & 6.05 & & & \\
\hline A. lanata & & & & 15.80 & & & & & 3.10 & & & \\
\hline A. officinalis & 4.93 & 60.68 & & & 197.43 & & & & 9.92 & & & \\
\hline A.cylindrica & & & & & & 4.27 & & & & & & \\
\hline Ae. floridum & & & & 22.58 & & & & & & 5.91 & & \\
\hline B. gymnorrhiza & & & & & & 60.5 & & & & & & \\
\hline B. parviflora & & & & & & 7.53 & 50.27 & 137.11 & 1.42 & 154.15 & 184.1 & 237.46 \\
\hline B. sexangula & & & & & & & & & 41.87 & 0.64 & & \\
\hline C. tagal & & & & & 20.84 & 5.18 & & & & & & \\
\hline C. decandra & & & & & & & & 18.18 & 0.26 & & & \\
\hline N. fruticans & & & & & & & & & & & & \\
\hline R. mucronata & 68.73 & - & - & & & & 33.91 & 40.72 & 15.46 & & 0.75 & 1.12 \\
\hline R. stylosa & & & & & & & 125.3 & 120.4 & & & 330.0 & 368.8 \\
\hline R. apiculata & 0.42 & 15.77 & 48.07 & 0.16 & & 1.02 & & & 20.09 & 34.3 & 46.12 & 51.93 \\
\hline S. alba & 466.39 & 449.73 & 30.05 & & & & & & & & & \\
\hline X. mekongensis & & & & & 36.55 & & & & & 193.15 & 31.39 & 62.00 \\
\hline X. moluccensis & & & & & & 42.90 & & & & 0.4 & 61.6 & \\
\hline $\begin{array}{l}\text { A. cylin } \\
\text { drica }\end{array}$ & & & & & & & & & & & & \\
\hline
\end{tabular}

The total carbon stock from biomass and necromass in Teling, Rap-rap, Pungkol and Wawontulap was given in table 3 . The carbon stock in biomass was highest than carbon stock in necromass. This data indicated that conserving mangrove plant species is crucial in $\mathrm{CO}_{2}$ mitigation.

Table 3. Carbon stock from biomass and necromass of mangrove plant trees

\begin{tabular}{lllll}
\hline Sites & Plots & $\begin{array}{l}\text { Biomass } \\
\left(\mathrm{Mg} \mathrm{ha}^{-1}\right)\end{array}$ & Necromass $\left(\mathrm{Mg} \mathrm{ha}^{-1}\right)$ & $\begin{array}{l}\text { Total } \\
\left(\mathrm{Mg} \mathrm{ha}^{-1}\right)\end{array}$ \\
\hline Teling & I & 540.47 & 141.00 & 681.47 \\
& II & 526.20 & 59.80 & 586.00 \\
& III & 128.10 & 7.99 & 136.09 \\
& Total & 1194.77 & 208.79 & 1403.56 \\
\hline Rap-rap & I & 837.90 & 12.46 & 850.36 \\
& II & 287.08 & 9.28 & 296.36 \\
& III & 659.70 & 16.70 & 676.40 \\
& Total & 1784.68 & 38.44 & 1823.12 \\
\hline Pungkol & I & 96.71 & 4.21 & 100.92 \\
& II & 208.05 & 16.75 & 224.80 \\
& III & 98.17 & 56.55 & 154.72 \\
& Total & 402.93 & 77.51 & 480.44 \\
\hline
\end{tabular}


Mangrove Vegetation Structure and Its Carbon Stock Potency in Bunaken National Park, ....

\begin{tabular}{lllll}
\hline Wawontulap & I & 387.51 & 23.10 & 410.61 \\
& II & 356.96 & 111.55 & 468.51 \\
& III & 390.03 & 21.30 & 411.33 \\
& Total & 1134.50 & 155.95 & 1290.45 \\
\hline
\end{tabular}

The content of carbon stock were influenced by biomass and necromas [19] [27]. Scholar point out that the ability of plant to absorb $\mathrm{CO} 2$ in atmosphere and stored into wood and plant biomass is important in global warming mitigation strategy [28]. The evaluation of carbon stock in mangrove ecosystems were varies. The highest carbon stock found at Rap-rap (ca. 1823,12 $\mathrm{Mg} \mathrm{ha}^{-1}$ ) and the lowest was found at Wawontulap (ca. $411,33 \mathrm{Mg} \mathrm{ha}^{-1}$ ). The carbon stock variety among sites and observed station were the result of the difference vegetation structure and composition. These data shows that mangrove is the important ecosystem in the earth in global carbon storage [28] [29] [30] [31].

Table 4. The total carbon stock of mangrove forest at Teling, Rap-rap, Pungkol and Wawontulap

\begin{tabular}{lllll}
\hline No & Sites & $\begin{array}{l}\text { Biomass } \\
\left(\mathrm{Mg} \mathrm{ha}^{-1}\right)\end{array}$ & $\begin{array}{l}\text { Necromass } \\
\left(\mathrm{Mg} \mathrm{ha}^{-1}\right)\end{array}$ & $\begin{array}{l}\text { Total } \\
\left(\mathrm{Mg} \mathrm{ha}^{-1}\right)\end{array}$ \\
\hline 1. & Teling & 1194.77 & 208.79 & 1403.56 \\
2. & Rap-rap & 1784.68 & 38.44 & 1823.12 \\
3. & Pungkol & 402.93 & 77.51 & 480.44 \\
4. & Wawontulap & 390.03 & 21.30 & 411.33 \\
\hline & Total & 1134.50 & 155.95 & 1290.45 \\
\hline
\end{tabular}

\section{Conclusion}

Mangrove ecosystem in the Bunaken National Park, North Sulawesi, is the important sites for carbon captured and stored in biosphere system. There are about 18 mangrove species growing in coastal area of Bunaken, namely A. marina, A. lanata, A. cylindrica, A. officinalis, A.cylindrica, Ae. floridum, B. gymnorrhiza, B. parviflora, B. sexangula, C. tagal, C. decandra, N. fruticans, R. mucronata, R. stylosa, R. apiculata, $S$. alba, X. mekongensis, and X. moluccensis. In Teling areas, Rhizophora mucronata and Soneratia alba become two co-dominant species in plot 1, Soneratia alba become important species in plot 2, and Rhizophora apiculata is the important species in plot 3. Avicennia marina become the most important species to characterized mangrove ecosystem in Rap-rap. In Pungkol areas, Bruguiera sexangula has highest value of important value index in Plot 1 , followed by $R$. mucronata in Plot 2 and B. parviflora in plot 3 . In Wawontulap areas, $B$. parviflora has the highest value of important value index in Plot 1, 2 and 3. The highest carbon stock was found at Rap-rap (ca. 1784,68 Mg/ha) and the lowest was found at Wawontulap (390,03 $\mathrm{Mg} \mathrm{ha}^{-1}$ ). The highest necromass was found at Teling (ca 208,79 $\mathrm{Mg} \mathrm{ha}^{-1}$ ) and the lowest was found at Wawontulap (ca. 21,30 Mg ha$1)$.

\section{Acknowledgements}

We would like to thank Rector University of Brawijaya Malang and Rector Manado State University in Tondano. We also like to thank Head of Graduate Program of Agriculture, Brawijaya University and Dean of Faculty of Agriculture Brawijaya university. Funding for this project provided through the Indonesian Higher Education Scholarship. The authors wish to thank laboratory member of Soil Laboratory and mapping, University of Brawijaya.

\section{References}

[1]. P. Saenger, E.J. Hegerl and J.D.S.Davie, Global Status of Mangrove Ecosystem (IUCN-UNEP \& WWF, 1983).

[2]. IPCC, Good practice guidance for land use, in J. Penman et al., eds., Land-Use Change and Forestry (Institute for Global Environmental Strategies (IGES) for the IPCC), Kanagawa, Japan 2001.

[3]. DM. Alongi, Present state and future of the world's mangrove forests. Environmental conservation, 29(03), 2002. 331-349.

[4]. JB. Kauffman, C. Heider, G.C. Thomas, A.D. Kathleen and D.C.Donato. Ecosystem Carbon Stocks of Micronesian Mangrove Forests. Article Wetlands February, US Government, 2011.

[5]. UNEP (United Nations Environment Programme). Annual Report Seeizing The Green Opportunity. Produced by UNEP Division of Communications and Public Information, Publishing Service Section Nairobi, 2009.

[6]. PS. Bhishma, SS. Pandey, A. Pandey, EB. Rana, S. Bhattarai, TR. Banskota, S. Charmakar and R. Tamrakar, Forest Carbon Stock Measurement; Guidelines for measuring carbon stocks in community-managed forests (ANSAB; FECOFUN; ICIMOD, 2010).

[7]. H. Qiang, MD. Bertness, JF. Bruno, Bo Li, G. Chen, TC. Coverdale, AH. Altieri, J.Bai1, T. Sun, SC. Pennings, J. Liu, PR. Ehrlich and B. Cui. Economic Development And Coastal Ecosystem Change In China. Scientific Reports, 4, $2014,1-9$.

[8]. P. Polomé, S. Marzetti and A.Van Der Veen, Economic and social demands for coastal protection. Coastal engineering, 52(10), 2005, 819-840.

[9]. A. Yamasaki, An overview of $\mathrm{CO} 2$ mitigation options for global warming-Emphasizing CO2 sequestration options. Journal of Chemical Engineering of Japan, 36(4), 2003, 361-375.

[10]. SI. Plasynski, JT.Litynski, HG.McIlvried and RD.Srivastava, Progress and new developments in carbon capture and storage. Critical Reviews in Plant Science, 28(3), 2009, 123-138.

[11]. L. Hakim and N. Nakagoshi, Ecotourism and Climates changes: the ecolodge contribution in global warming mitigation. Journal of Tropical Life Science, 4(1), 2014, 26-32. 
[12]. LM. Curran, SN. Trigg, AK. McDonald, D. Astiani, YM. Hardiono, P. Siregar and E. Kasischke, Lowland forest loss in protected areas of Indonesian Borneo, Science, 303(5660), 2004, 1000-1003.

[13]. L. Hakim, and H. Miyakawa, Plant trees species for restoration program in Ranupani, Bromo Tengger Semeru National Park Indonesia. Biodiversity Journal, 4(3), 2014, 387-394.

[14]. T. Whitten, M. Mustafa and G.S. Henderson. Ecology of Sulawesi (Tuttle Publishing, 2002).

[15]. J. Kimbal, Kajian Kerawanan Degradasi Ekosistem Hutan Mangrove Berdasarkan Analisis Vegetasi di Kawasan Taman Nasional Bunaken Bagian Selatan Sulawesi Utara (The Study on Susceptibility Degradation of Mangrove Forest Ecosystem in Southern Bunaken National Park, North Sulawesi). Jurnal Payangka 2(3), 2008, 24-30

[16]. L. Hakim, M. Soemarno and SK. Hong, Challenges for conserving biodiversity and developing sustainable island tourism in North Sulawesi Province, Indonesia. Journal of Ecology and Field Biology, 35(2), 2012, 61-71.

[17]. A. Pangemanan, Maryunani, L. Hakim and B. Polii. Economic analisys of Bunaken National Park Ecotourism Area based on the carrying capacity and visitation level. Asian Transactions on Basic and Applied Sciences, 2(2), 2012, 34-40.

[18]. M. Kent and P. Cooker. Vegetation description and analysis. A Practical Approach 9Willey and Sons, New York, 1994).

[19]. K. Hairiah and S. Rahayu. Pengukuran Karbon Tersimpan. Di Berbagai Macam Penggunaan Lahan (Measurement of stored carbon in different landuses), (World Agroforestry Centre, Bogor, 2007).

[20]. W. MacNae, A general account of the fauna and flora of mangrove swamps and forests in the Indo-West-Pacific region. Advances in marine biology, 6,1969, 73-270.

[21]. N. Duke, K. Kathiresan, S.G. Salmo III, ES. Fernando, JR.Peras, S. Sukardjo, T. Miyagi, J. Ellison, N.E. Koedam, Y. Wang, J. Primavera, O. Jin Eong, J. Wan-Hong Yong and V.Ngoc Nam. 2010. Avicennia marina. The IUCN Red List of Threatened Species. Version 2014.

[22]. AE. Lugo, Ecology of Mangrove: Successional or Steady State, Bio Tropical, 12, 1980, 65-72.

[23]. KLH. Agenda 21 Indonesia: Strategi Nasional Umum Pembangunan Terlanjutkan (Agenda 21 of Indonesia: General National Strategy of Sustainable Development). National Office of Environmental Management Ministry, Jakarta 1997.

[24]. R. Dahuri, J. Rais, SP. Ginting and MJ. Sitepu. Pengelolaan Sumberdaya Wilayah Pesisir dan Lautan Secara Terpadu (Integrated management of coastal and marine resources) (PT. Pradnya Paramita, Jakarta, 2001).

[25]. A. Satria, Y. Matsuda, and M. Sano, Questioning Community-Based Coral Reef Management Systems: Case Study of Awig-Awig in Gili Indah, Indonesia. Journal of Environment, Development and Sustainability, 8, 2006, 99-118.

[26]. K. Kathiresan and N. Rajendran, Coastal mangrove forests mitigated tsunami. Estuarine, Coastal and Shelf Science, 65(3), 2005, 601-606.

[27]. K. Hairiah, S. Rahayu and Berlian. Layanan Lingkungan Agroforestry Berbasis Kopi; Cadangan Karbon dalam Biomassa Pohon dan Bahan Organik Tanah (Studi Kasus dari Sumberjaya, Lampung Barat) (Environmental services of coffee based agroforestry; carbon stock in tree biomass and soil organic matter. Case study in Sumberjaya, West Lampung), Agrivita, 28, 2006, $298-309$.

[28]. R. Ray, N. Majumder, C. Chowdhury and TK. Jana, Wood Chemistry and Density: An Analog for Response To The Change of Carbon Sequestration in Mangroves. Journal Carbohydrate Polymers, 90, 2012, 102-108.

[29]. LA. Trotta, AD. McKinnona, DM. Alongia, A. Davidsona and MA. Burfordb. Carbon and Nitrogen Processes In a Mangrove Creek Receiving Shrimp Farm Effluent. Journal Estuarine, Coastal and Shelf Science, 59, 2004, 197-207.

[30]. SJ. Livesley and SM. Andrusiak, Temperate Mangrove and Salt Marsh Sediments are a Small Methane and Nitrous Oxide Source But Important Carbon Store. Journal Estuarine, Coastal and Shelf Science, 97, 2012: 19-27.

[31]. GJ. Trevor, HR. Ratsimba, L. Ravaoarinorotsihoarana , G. Cripps and A. Bey, Ecological Variability and Carbon Stock Estimates of Mangrove Ecosystems in Northwestern Madagascar. Forests, 5(1), 2014, 177-205. 